\title{
HIV-1 Tat protein directly induces mitochondrial membrane permeabilization and inactivates cytochrome $c$ oxidase
}

\author{
H Lecoeur ${ }^{1,2}$, A Borgne-Sanchez ${ }^{1,3,4}, O$ Chaloin ${ }^{5}$, R El-Khoury ${ }^{6,7}$, M Brabant $^{1}$, A Langonné ${ }^{1}$, M Porceddu ${ }^{3,4}$, J-J Brière ${ }^{6,7}, N_{\text {Buron }}^{3,4}$,
} D Rebouillat ${ }^{1}$, C Péchoux ${ }^{8}$, A Deniaud ${ }^{9}$, C Brenner ${ }^{9,10,11}$, J-P Briand ${ }^{5}$, S Muller ${ }^{5}$, P Rustin ${ }^{6,7,13}$ and E Jacotot ${ }^{\star, 1,3,6,7,12,13}$

The Trans-activator protein (Tat) of human immunodeficiency virus (HIV) is a pleiotropic protein involved in different aspects of AIDS pathogenesis. As a number of viral proteins Tat is suspected to disturb mitochondrial function. We prepared pure synthetic full-length Tat by native chemical ligation (NCL), and Tat peptides, to evaluate their direct effects on isolated mitochondria. Submicromolar doses of synthetic Tat cause a rapid dissipation of the mitochondrial transmembrane potential $\left(\Delta \Psi_{m}\right)$ as well as cytochrome $c$ release in mitochondria isolated from mouse liver, heart, and brain. Accordingly, Tat decreases substrate oxidation by mitochondria isolated from these tissues, with oxygen uptake being initially restored by adding cytochrome $c$. The anionchannel inhibitor 4,4'-diisothiocyanostilbene-2,2'-disulfonic acid (DIDS) protects isolated mitochondria against Tat-induced mitochondrial membrane permeabilization (MMP), whereas ruthenium red, a ryanodine receptor blocker, does not. Pharmacologic inhibitors of the permeability transition pore, Bax/Bak inhibitors, and recombinant $\mathrm{Bcl}-2$ and $\mathrm{Bcl}-\mathrm{XL}$ proteins do not reduce Tatinduced MMP. We finally observed that Tat inhibits cytochrome $c$ oxidase (COX) activity in disrupted mitochondria isolated from liver, heart, and brain of both mouse and human samples, making it the first described viral protein to be a potential COX inhibitor. Cell Death and Disease (2012) 3, e282; doi:10.1038/cddis.2012.21; published online 15 March 2012

Subject Category: Experimental Medicine

Mitochondria, the energy-producing organelles of eukaryotes, generate cellular energy in the form of ATP (adenosine triphosphate) coupling substrates oxidation and the proton gradient established along with electron flow through the electron transfer chain of the respirasome (complexes I, III, and IV) to the ATP synthesis by the F1FO-ATP synthase (complex V). ${ }^{1-3}$ Mitochondria also play a key role in apoptosis and related forms of cell death. ${ }^{4,5}$ Mitochondrial fission, inner membrane permeabilization (IMP; leading to mitochondrial transmembrane potential $\left(\Delta \Psi_{\mathrm{m}}\right)$ loss and matrix cofactor release), rearrangements of mitochondrial lipids, and outer membrane permeabilization (OMP; resulting in the release of, and/or access to, intermembrane space proteins, including cytochrome c) are pivotal events in the apoptotic process. ${ }^{6-8}$
As a corollary, many viruses have evolved to encode proteins that directly target mitochondria for modulating apoptosis. ${ }^{9,10}$

The human immunodeficiency virus type 1 (HIV-1) transactivator of transcription (Tat) protein is an important factor in the HIV-induced pathogenesis of AIDS, contributing to immune dysfunction, Kaposi's sarcoma, HIV-associated dementia, and cardiomyopathy. ${ }^{11,12}$ In infected cells, Tat transactivates virus gene transcription and is essential for replication. During acute infection of $\mathrm{T}$ cells by HIV, Tat released in the stromal microenvironment of infected cells can bind and/or be efficiently taken up by most cell types. ${ }^{13}$ Although antiretroviral therapy has proven efficacy to reduce viral load, once proviral DNA is formed, such treatment does not prevent production of early viral proteins Tat, Rev, and Nef. ${ }^{14,15}$ The outcome of Tat

\footnotetext{
${ }^{1}$ Theraptosis S.A., Pasteur BioTop Research Laboratory, Institut Pasteur, Paris 75015, France; ${ }^{2}$ Institut Pasteur, Unité d'Immunophysiologie et Parasitisme Intracellulaire, Département de Parasitologie et Mycologie, Paris 75015, France; ${ }^{3}$ Theraptosis S.A., R\&D Laboratories, Biocitech Technology Park, Romainville 93230 , France; ${ }^{4}$ Mitologics S.A.S., Hôpital Robert Debré, Paris 75019, France; ${ }^{5}$ CNRS UPR 9021, Institut de Biologie Moléculaire et Cellulaire, Strasbourg 67000, France; ${ }^{6}$ Inserm U676, Hôpital Robert Debré, Paris 75019, France; ${ }^{7}$ Université Paris 7 UMR676, Faculté de Médecine Denis Diderot, Paris 75019, France; ${ }^{8}$ INRA, UR1196 Génomique et Physiologie de la Lactation, Plateau de Microscopie Électronique MIMA2, Jouy-en-Josas 78352, France; ${ }^{9} \mathrm{CNRS}$ FRE 2445 , Université de Versailles/ St Quentin, Versailles 78035, France; ${ }^{10}$ Inserm U769, Signalisation et Physiopathologie Cardiaque, Châtenay-Malabry 92296, France; ${ }^{11}$ Université Paris-Sud, Faculté de Pharmacie, Châtenay-Malabry 92296, France and ${ }^{12}$ Imperial College London, Department of Reproductive Biology, Cancer Division, Hammersmith Hospital, London W12 ONN, UK

*Corresponding author: E Jacotot, Inserm U676, Hôpital Robert Debré, 48 Boulevard Sérurier, Paris 75019, France. Tel: + 33140031932 ; Fax: +33 140 03 19 95; E-mail: etienne.jacotot@inserm.fr or e.jacotot@imperial.ac.uk

${ }^{13}$ These authors shared senior co-authorship.

Keywords: HIV-1; Tat; mitochondria; cytochrome $c$ oxidase

Abbreviations: ATP, adenosine triphosphate; BA, bongkrekic acid; BCB, Bax channel inhibitor; BIP, Bax-inhibiting peptide; mCICCP, $m$-chlorocarbonylcyanide phenylhydrazone; CsA, cyclosporin A; COX, cytochrome $c$ oxidase; DIDS, 4,4'-diisothiocyanostilbene-2,2'-disulfonic acid; $\Delta \Psi \mathrm{m}$, mitochondrial transmembrane

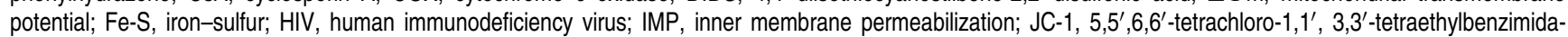
zolylcarbocyanine iodide; MMP, mitochondrial membrane permeabilization; Mn-SOD, manganese superoxide dismutase; MOPS, 3-[N-morpholino] -propanesulfonic acid; NCL, native chemical ligation; OMP, outer membrane permeabilization; PTP, permeability transition pore; PR, HIV protease; RCR, respiratory control ratio; Rh123, rhodamine 123; RYR, ryanodine receptor; Tat, Trans-activator of transcription; TES, N-[tris(hydroxymethyl)methyl]-2-aminoethanesulfonic acid, 2-[(2-hydroxy1,1-bis(hydroxymethyl)ethyl)amino]ethanesulfonic acid

Received 07.6.11; revised 25.1.12; accepted 09.2.12; Edited by A Finazzi-Agro'
} 


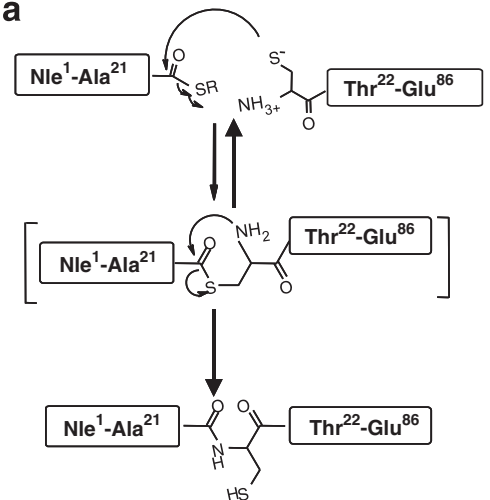

b
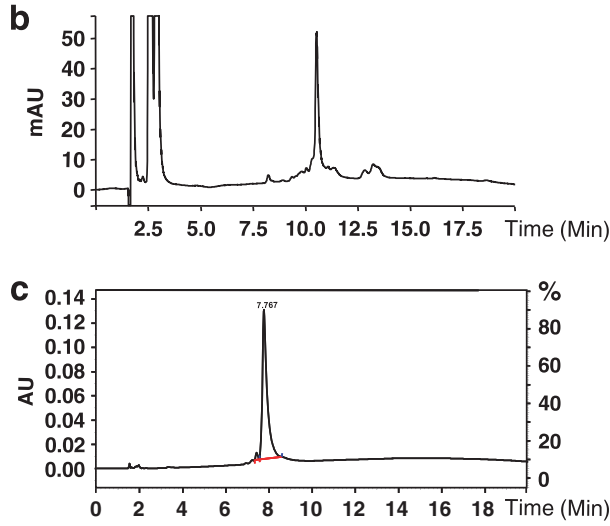

d

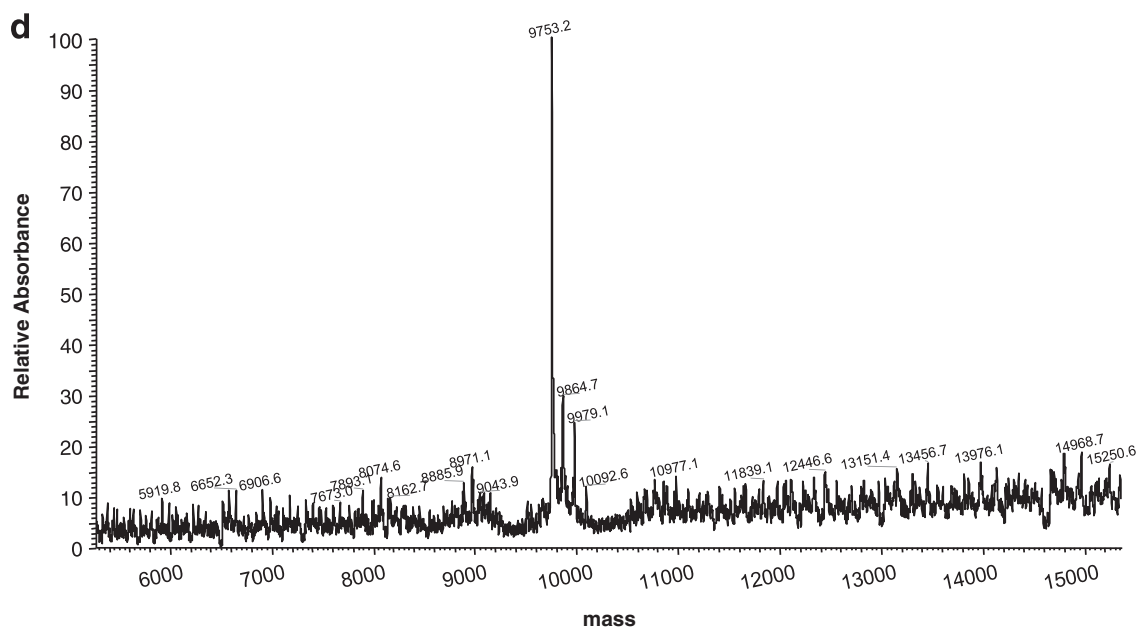

Figure 1 Tat [1-86] preparation. (a) Principle of full-length Tat synthesis by NCL. (b) HPLC profile of the reaction mixture after $36 \mathrm{~h}$ and before purification. Gradient $5-20^{\prime}$ $-65 \%$ B, col. C4, $1.2 \mathrm{ml} / \mathrm{min}, 220 \mathrm{~nm}$. (c) HPLC profile of [1-86]Tat after purification. Gradient $5-20^{\prime}-65 \%$ B, col. C4, $1.2 \mathrm{ml} / \mathrm{min}, 220 \mathrm{~nm}$. The purity was $97.2 \%$. (d) Mass spectrum of [1-86] Tat. Mr observed: $9753.2(\mathrm{M}+1)$, Mr calculated: 9751.6

activity is dependent on its concentration, the cell types involved, and whether activity is mediated within infected cells or through paracrine-like effect to uninfected bystander cells. $^{16}$

Several in vitro studies suggest that Tat may interfere directly or indirectly with mitochondrial functions. For instance, Tat-expressing cell lines have reduced expression of the manganese superoxide dismutase (Mn-SOD), a mitochondrial enzyme that is part of the cellular defense system against oxidative stress. ${ }^{17}$ Under low serum conditions, Tat translocation from the nucleus to the mitochondria, correlating with $\Delta \Psi_{\mathrm{m}}$ dissipation, reactive oxygen production, and apoptosis, was also shown in Tat-expressing cell. ${ }^{18}$ Tat may also bind tubulin and polymerized microtubules, leading to the alteration of microtubule dynamics and activation of a mitochondriadependent apoptotic pathway. ${ }^{19,20}$ Using recombinant HIV-1 Tat1-72 protein, Norman et al. ${ }^{21}$ reported that Tat can induce a decrease in free mitochondria calcium in primary neurons, and inhibits mitochondrial complexes III and IV in mitochondria isolated from juvenile rat brain. Moreover, transgenic mice expressing Tat selectively in cardiac myocytes present cardiac dysfunction associated with severe mitochondrial damage. ${ }^{22}$ Based on these premises, we investigated if pure, biologically active, synthetic Tat may directly interact with mitochondria from different tissues, and which mitochondrial target(s) Tat would possibly hit.

\section{Results}

Full-length Tat synthesis. The full-length [1-86] Tat protein is synthesized using the native chemical ligation (NCL) method initially introduced by Dawson et al. ${ }^{23}$ The reaction is performed between two fully unprotected peptides, the $\mathrm{N}$ terminal segment having a C-terminus thioester and the $\mathrm{C}$ terminal segment having an $\mathrm{N}$-terminus cysteine residue (Figure 1a). The first step is a trans-thioesterification of the $\mathrm{C} \alpha$ thioester by the thiol function of the Cys residue, and is followed by a spontaneous $\mathrm{S}$ to $\mathrm{N}$ acyl shift to obtain a native amide bond. The HPLC profile of the reaction products after completion is shown in Figure $1 \mathrm{~b}$. The Tat protein is further isolated at a purity above $95 \%$ (Figure 1c) and is characterized by mass spectrometry (Figure 1d). The synthesis of this protein by a classical solid-phase protocol has already been reported. ${ }^{24}$ The chemical ligation used in the present study represents an alternative and convenient way to obtain a highly purified, well-characterized Tat protein in relatively large amounts (up to $100 \mathrm{mg}$ ). This 

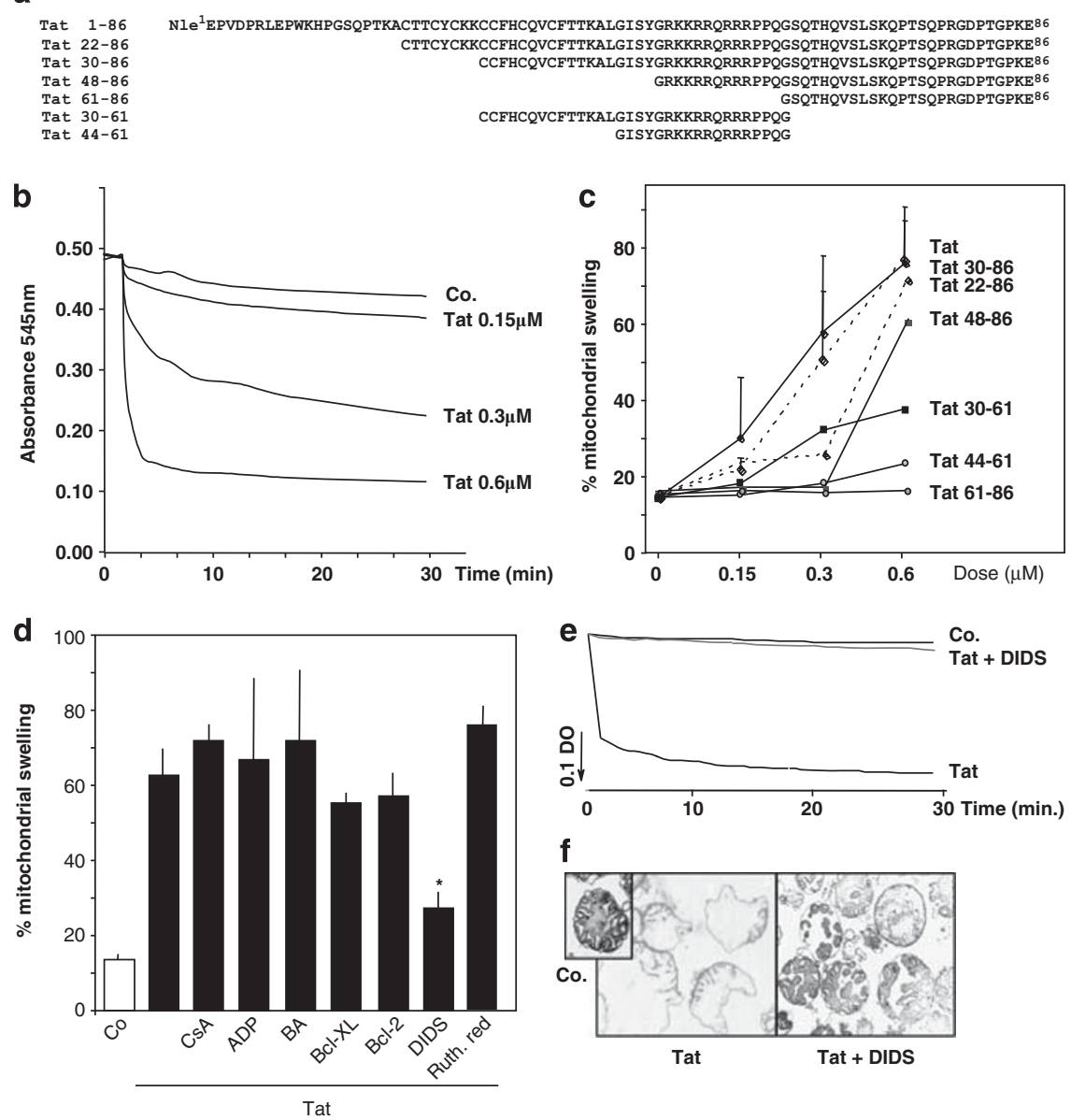

Figure 2 Tat-induced swelling in liver isolated mitochondria. (a) Sequence of full-length Tat[1-86] (HIV-1 Lai) and Tat derived peptides. (b) Dose/time response of Tat[186]-induced swelling. Isolated mouse liver mitochondria were exposed to full-length Tat at the indicated concentrations and mitochondrial swelling (measured as $90^{\circ}$ light scattering at $545 \mathrm{~nm}$ ) was monitored continuously. (c) Comparative analysis of the effect of Tat-derived peptides on mitochondrial swelling. Isolated mouse liver mitochondria were exposed to the indicated concentrations of Tat-derived peptides. Mitochondrial swelling was monitored for $30 \mathrm{~min}$. Percentages of mitochondrial swelling were calculated as described under Materials and Methods. Data are means ( \pm S.D.) of three independent experiments. (d) Evaluation of PTP-related inhibitors on mitochondrial swelling. Liver mitochondria were exposed to Tat[1-86] $(0.3 \mu \mathrm{M} ; 30 \mathrm{~min})$ in the presence or absence (Co.) of the following compounds (added 5 min before Tat): cyclosporin A (CsA; $30 \mu \mathrm{M})$, ADP $(1 \mathrm{mM})$, bongkrekic acid $(\mathrm{BA} ; 50 \mu \mathrm{M})$, Bcl-2 $(400 \mathrm{nM})$, Bcl-XL $(400 \mathrm{nM})$, or DIDS $(5 \mu \mathrm{M})$. Histograms represent mean values $( \pm \mathrm{S} . \mathrm{D}$.) of five independent experiments. ${ }^{*} P<0.05$. (e) Time course follow-up of absorbance characteristics of mouse isolated liver mitochondria in the absence of $\mathrm{Co}$. and the presence of either Tat[1-86] or Tat $+5 \mu \mathrm{M}$ DIDS. Excess of DIDS was removed by centrifugation before Tat was added at the final concentration of $0.3 \mu \mathrm{M}$. (f) Ultrastructure of Tat-treated mitochondria. Representative electron micrographs of isolated liver mitochondria treated or not (Co.) with Tat[1-86] $(30 \mathrm{~min} ; 0.15 \mu \mathrm{M})$ and optionally pre-treated with DIDS $(5 \mu \mathrm{M} ; 1$ min before Tat addition)

synthetic Tat (sTat) was shown to be fully functional in transactivation assays. ${ }^{25-27}$

Tat[1-86] induces swelling of isolated mitochondria. When added to mouse liver mitochondria, submicromolar concentrations of synthetic Tat[1-86] (Figure 2a) induce a rapid dose-dependent mitochondrial swelling (Figure $2 b$ ). The effect of free holo-Tat on isolated mitochondria is fully mimicked by Tat[22-86] and Tat[30-86], partly by Tat[48-86], but is not observed with Tat[30-61], Tat[44-61] and Tat[61-86], (Figure 2c), indicating that main functional domains (i.e., the core region [38-48], the basic region [49-59], the glutaminerich region [60-72], and the C-terminus) are required for efficient Tat-induced mitochondrial swelling. Permeability transition pore (PTP) inhibitors including cyclosporin A (CsA, a cyclophilin D ligand), ADP, and bongkrekic acid (BA, an adenine nucleotide translocase ligand) are inefficient to protect mitochondria from Tat-induced swelling (Figure 2d). Accordingly, when Tat is added to liposomes containing a PTP-enriched fraction, ${ }^{28,29}$ it does not induce proteoliposome permeabilization (Supplementary Figure S1). Thus, in contrast to Vpr, another HIV-1-encoded mitochondrial membrane permeabilization (MMP) inducer, ${ }^{29,30}$ Tat-induced MMP is not related to the PTP.

Tat-induced swelling of liver mitochondria is reduced by pretreatment of mitochondria with the broad-spectrum anion channel inhibitor 4,4'-diisothiocyanostilbene-2,2'-disulfonic acid (DIDS), but not with recombinant $\mathrm{Bcl}-2$ and $\mathrm{Bcl}-\mathrm{XL}$ (Figure 2d). Noticeably, the protective effect of DIDS is still observed if DIDS-treated mitochondria are washed before Tat addition (Figure 2e). Ultrastructural studies of isolated mitochondria confirm that, in sucrose buffer, Tat addition 


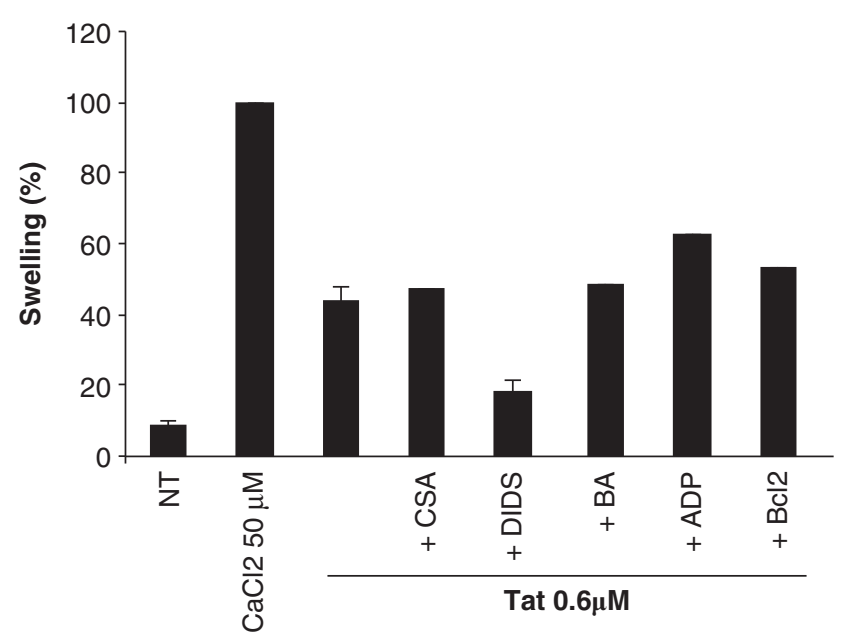

Figure 3 Tat-induced swelling in heart-isolated mitochondria. Isolated mouse heart mitochondria were exposed to full-length Tat[1-86] $0.6 \mu \mathrm{M}$ and mitochondrial swelling (measured as $90^{\circ}$ light scattering at $545 \mathrm{~nm}$ ) was monitored for $30 \mathrm{~min}$. When indicated, mitochondria were preexposed for $5 \mathrm{~min}$ in the presence or absence of the following compounds: cyclosporin A (CsA; $30 \mu \mathrm{M})$, ADP (1 mM), bongkrekic acid (BA; $50 \mu \mathrm{M}), \mathrm{Bcl}-2(400 \mathrm{nM})$, or DIDS $(5 \mu \mathrm{M})$. Then, mitochondria were incubated with Tat[1-86] $(0.3 \mu \mathrm{M} ; 30 \mathrm{~min})$. Percentages of mitochondrial swelling (left panel) were calculated as described under Materials and Methods. Positive control was defined by the addition of $50 \mu \mathrm{M} \mathrm{CaCl}_{2}$. Histograms represent mean values ( \pm S.D.) of three independent experiments

readily induces an outer membrane disruption of liver mitochondria, resulting in numerous protrusions of the inner membrane. DIDS pretreatment strongly prevents these Tat-induced morphological changes in liver mitochondria (Figure 2f). Similar results were found with synthetic Tat was added on mitochondria isolated from mice heart (Figure 3), indicating that Tatinduced mitochondrial swelling is not restricted to liver mitochondria, and suggesting a common PTP-independent mechanism. However, under our experimental conditions, and using two different protocols for isolation, we have found that brain mitochondria were not sensitive to calcium-induced (or Tat-induced) swelling (data not shown).

Reportedly, Tat can also trigger calcium release from mitochondria, ${ }^{21}$ possibly through a ryanodine receptor (RYR)dependent pathway. ${ }^{31}$ To investigate the possibility of a direct interaction with Tat at the mitochondrial level, we pretreated isolated mitochondria with ruthenium red, a RYR blocker also known to inhibit the mitochondrial $\mathrm{Ca}^{2+}$ uniporter. Ruthenium red blocked calcium-induced mitochondrial swelling but had no effect against Tat-mediated MMP in liver (Figure 2d) and heart mitochondria (Supplementary Figure S2).

Characterization of Tat-induced $\Delta \Psi_{m}$ and cytochrome $c$ release in isolated mitochondria. Real-time and fixed-time flow cytometry analysis of $\Delta \Psi_{\mathrm{m}}{ }^{32}$ indicates that full-length Tat induces a rapid $\Delta \Psi_{\mathrm{m}}$ loss in liver mitochondria, heart mitochondria, and brain mitochondria as well (Figures $4 a$ and b). Tat-induced $\Delta \Psi_{\mathrm{m}}$ loss is inhibited by DIDS in mitochondria isolated from these three tissues (Figure $4 b$ ). Contrary to DIDS, PTP inhibitors and recombinant $\mathrm{Bcl}-2$ are unable to hamper Tat-induced $\Delta \Psi_{\mathrm{m}}$ loss (Figure $4 \mathrm{c}$ ). We also found that Tat-induced $\Delta \Psi_{\mathrm{m}}$ loss is associated with DIDSsensitive cytochrome $c$ release (Figures $3 d$ and e). As mitochondria isolated from heart and liver do not express Bax but do express low and high quantities of Bak, respectively (Supplementary Figure S3), we also investigated whether Bax-inhibiting peptide (BIP) or Bax channel inhibitor (BCB; which inhibits $\mathrm{Bax}$ and Bak oligomerization in the mitochondrial outer membrane ${ }^{33}$ ) might affect Tat-induced cytochrome $c$ release (Figures $4 \mathrm{f}$ and $\mathrm{g}$ ). Neither BIP nor BCB could modify Tat-induced cytochrome $c$ release. Taken together with the absence of the effect of Bcl-2 (Figures 2d and $4 \mathrm{c}$ ), one can suggest that Tat-induced MMP might be independent of the canonic Bax/Bak-mediated mitochondrial permeabilization pathway.

Tat inhibits substrate oxidation in mitochondria isolated from heart, brain, and liver. Compared with untreated organelles (Figure 5a, traces a, e, g), mitochondria preincubated with Tat[1-86] (Figure 5a, traces b, f, h) exhibit a severe deficiency in succinate oxidation. Adding cytochrome $c$ to Tat-treated mitochondria oxidizing succinate does not stimulate the rate of oxygen uptake (Figure $5 a$, traces $b, f, h$ ), suggesting that Tat inhibits respiratory chain function by an additional mechanism. Noticeably, DIDS partly prevents Tatinduced succinate oxidation defect and permits a full restoration of oxygen consumption by exogenous cytochrome $c$ (Figure 5a, trace $\mathrm{c}$ ). In contrast, RYR appears not to be implicated as we observed that respiratory control ratios (RCRs) measured using succinate as a substrate in heart mitochondria did not differ in the absence (RCR: 2.7) or presence (RCR: 2.8) of $1 \mu \mathrm{M}$ ruthenium red (Supplementary Figure S4). Tat-induced inhibition of substrate oxidation is dose dependent (Figure 5b). Interestingly, up to $5 \mu \mathrm{M}$ Tat, the addition of exogenous cytochrome $c$ reverses Tat-induced inhibition of substrate oxidation (Figure $5 \mathrm{~b}$ ). This suggests that Tat-induced OMP and IMP may be two independent/ successive events.

Full length HIV-1 Tat is a cytochrome $c$ oxidase (COX) inhibitor. The activity assays of complexes I-IV in brain mouse homogenate show that complex IV (but not electron transfer complexes I- III) is strongly inhibited (>95\%) by $1 \mu \mathrm{M}$ Tat[1-86] (Table 1). To determine if full-length Tat inhibits COX activity in liver mitochondria, we evaluated the effects of Tat[1-86] on the ability of COX to oxidize exogenous cytochrome $c$ in permeabilized organelles. ${ }^{34}$ In order to avoid medium-induced artifacts, experiments were performed in three different media classically used for swelling, respirometry, and COX enzymatic activity evaluations, respectively. In lauryl maltoside-treated liver mitochondria, Tat[1-86] strongly inhibits cytochrome $c$ oxidation whatever the medium considered (Figure 6a, panel 1), and this effect is not prevented by DIDS pretreatment (Figure 6b, panel 2). In contrast, Vpr52-96, another MMP-inducing HIV-related peptide, does not induce COX inhibition (Figure 6a, panel 3). Shorter Tat-derived peptides do not (Tat[44-61] and Tat[61-86]), or only poorly (Tat[30-86]), inhibit mitochondrial COX (Figure 6a, panel 4). COX inhibition by full-length Tat is not tissue specific as a dose-dependent COX inhibition is also observed in (lauryl maltoside) permeabilized mitochondria isolated from heart and brain (Figure $6 b$ ). We next determined the 

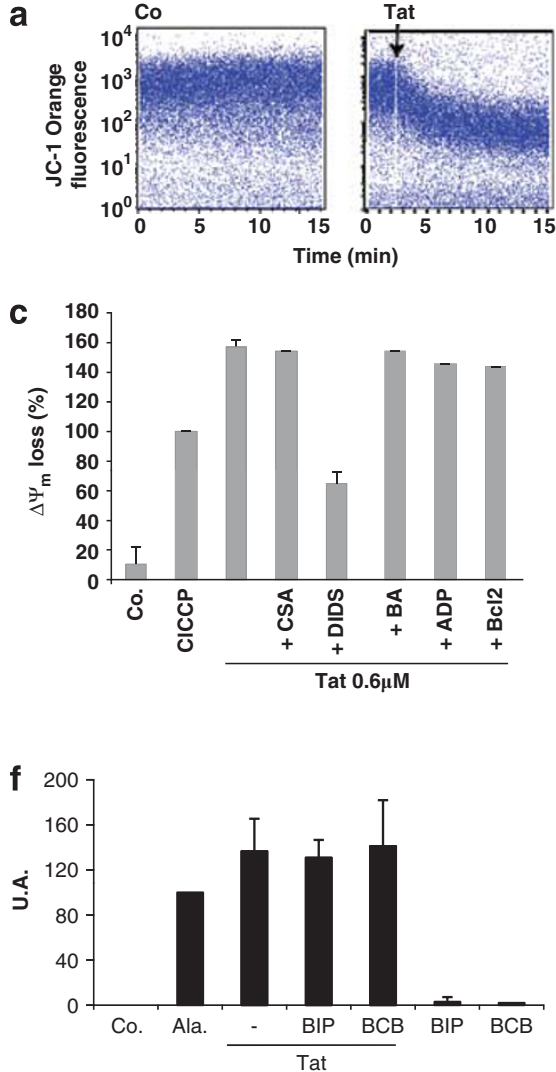

b

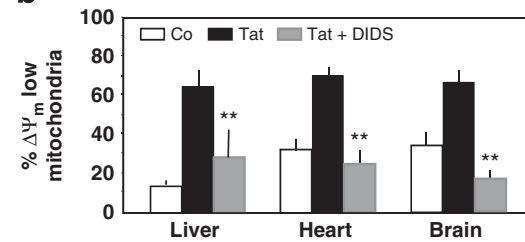

d

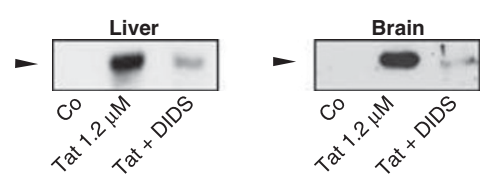

e
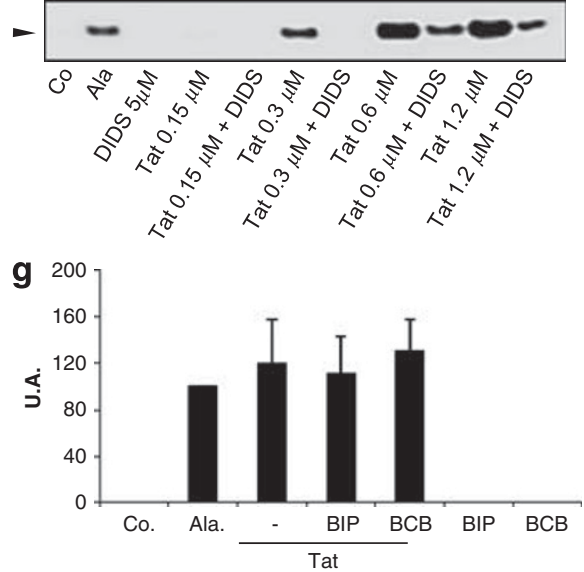

Figure 4 Permeabilization of inner and outer membranes induced by Tat in liver, brain, and heart mitochondria. (a) Real-time flow cytometry analysis of $\Delta \Psi_{\mathrm{m}}$ in Tattreated mitochondria. Basal fluorescence of JC-1-loaded liver mitochondria was recorded for 2 min. The organelles were then exposed (arrow) or not (Co.) to $0.3 \mu \mathrm{M} \mathrm{Tat}[1-86]$. The arrow indicates the time of Tat addition. Time-Fl-2 (orange fluorescence because of J-aggregate formation) dot plots are shown. (b) Fixed-time flow cytometry comparative analysis of $\Delta \Psi_{\mathrm{m}}$ in liver, heart, and brain mitochondria. Mitochondria were exposed to Tat (Tat concentration as in (a)) for 30 min in the absence (black bars) or presence (gray bars) of DIDS ( $5 \mu \mathrm{M}$; added 1 min before Tat), and compared with untreated mitochondria (white bars). Histograms represent mean values ( \pm S.D.) of three independent experiments. ${ }^{\star \star} P<0.01$. (c) Tat-induced $\Delta \Psi_{\mathrm{m}}$ loss in heart-isolated mitochondria. Isolated mouse heart mitochondria were exposed to full-length Tat[1-86] (0.6 $\left.\mu \mathrm{M}\right)$ and $\Delta \Psi_{\mathrm{m}}$ loss (fluorescence dequenching of Rhodamine 123) was monitored for $30 \mathrm{~min}$ by spectrofluorimetry. When indicated, heart mitochondria were preexposed for 5 min to Tat the following compounds: cyclosporin A (CsA; $30 \mu \mathrm{M}), \mathrm{ADP}(1 \mathrm{mM})$, bongkrekic acid (BA; $50 \mu \mathrm{M})$, Bcl-2 $(400 \mathrm{nM})$, or DIDS $(5 \mu \mathrm{M})$. Percentages of $\Delta \Psi_{\mathrm{m}}$ loss were calculated as described under Materials and Methods. Positive control was defined by the addition of $50 \mu \mathrm{M}$ CICCP. Histograms represent mean values $(n=3 \pm$ S.D.). (d-g) Tat-induced cytochrome $c$ release from isolated mitochondria. (d and e) Western blot analysis of Tat-induced cytochrome $c$ release. Liver (d), brain (d), and heart (e) isolated mitochondria were incubated or not for 5 min with DIDS $(5 \mu \mathrm{M}$; RT) centrifugated (to remove free DIDS) and mitochondrial pellet were resuspended and incubated 30 min at $37^{\circ} \mathrm{C}$ in the presence or absence of $0.15,0.3,0.6$, and $1.2 \mu \mathrm{M}$ Tat[ $[1-86]$. Then, supernatants from mitochondria $\left(6800 \mathrm{~g}\right.$ for $\left.10 \mathrm{~min} ; 4^{\circ} \mathrm{C}\right)$ were subjected to immunodetection of cytochrome (cyt) $c$. ( $\mathbf{f}$ and $\mathbf{g}$ ) Quantitation of cytochrome $c$ release. Isolated liver (f) and heart $(\mathbf{g})$ mitochondria were treated with $0.6 \mu \mathrm{M}$ of the synthetic Tat protein and mitochondrial supernatant was subjected to ELISA assays, given in percentage of release compared with $20 \mu \mathrm{g} / \mathrm{ml}$ alamethicin (Ala.; $100 \%$ of cytochrome $c$ release) $(n=3$ independent experiments)

kinetics properties of COX in liver mitochondria under our experimental conditions $\left(V_{\max }=73( \pm 8) / \mathrm{s} ; K_{\mathrm{m}}\right.$ (red cyt c) $=$ $1.95( \pm 0.8) \mu \mathrm{M})$. Tat addition to isolated liver mitochondria reduces $V_{\max }\left(V_{\max }[\mathrm{Tat}]=35( \pm 4) / \mathrm{s}\right)$ without any effect on

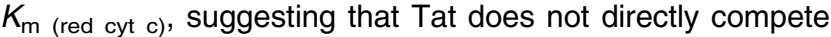
with cytochrome $c$ (Figure 6c). Finally, Tat[1-86] is able to inhibit COX activity in homogenates from various human tissues including liver, heart, brain, and skeletal muscle (Supplementary Figure S5).

\section{Discussion}

In the present study, we have investigated the potential direct effect of synthetic Tat protein (from HIV-1 Lai isolate; clade B) on mitochondria that could trigger pathogenic events. Based on the evidences obtained with isolated mitochondria (liver, heart, and brain), it appears that the HIV-1-encoded
Tat[1-86] protein directly interacts with mitochondrial membranes, triggering PTP-independent $\Delta \Psi_{\mathrm{m}}$ loss and cytochrome $c$ release. Under our experimental conditions, Tat also induces mitochondrial swelling in liver and heart mitochondria. All these Tat-induced MMP events are prevented by the general anion channel blocker DIDS but not by PTP inhibitors or Bax/Bak inhibitors.

We also report for the first time a severe decrease of succinate oxidation upon Tat addition to intact mitochondria from heart, brain, and liver mice. Interestingly, when Tat is added to these mitochondria after disruption, or to various human homogenates (liver, heart, brain, and skeletal muscle), a severe and specific COX inhibition is observed, whereas other mitochondrial respiratory chain complexes (I-III) are not affected. A previous report showed that recombinant HIV-1 Tat[1-72] could induce a slight decrease in rat brain complex III and IV activities. ${ }^{21}$ Our results do not confirm any effect of 

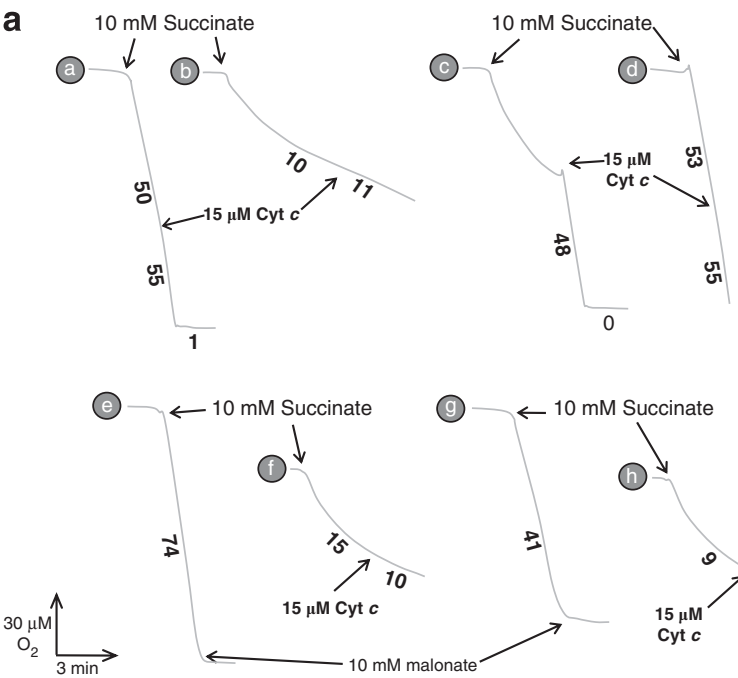

$\stackrel{7}{7}$
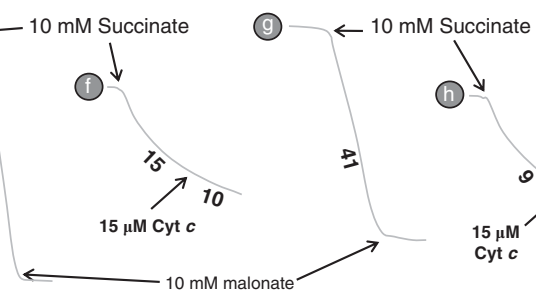

b

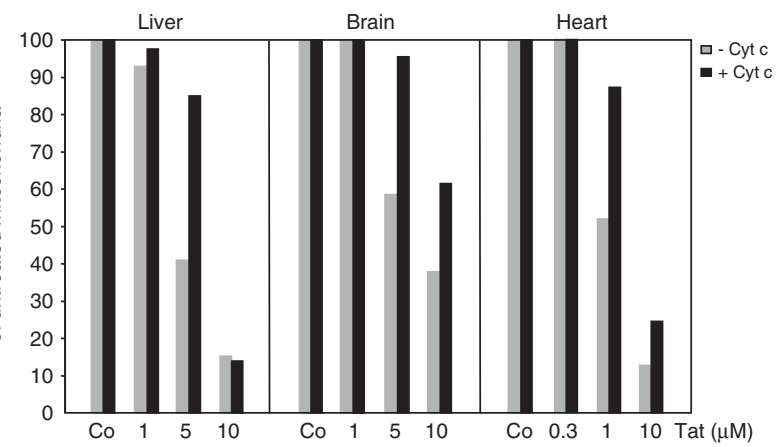

Figure 5 Oxidative properties of purified mitochondria exposed to Tat. (a) Oxygen consumption upon addition of the indicated reagents. Trace a: liver mitochondria (no pretreatment). Trace $\mathrm{b}$ : Liver mitochondria pretreated for $3 \mathrm{~min}$ with $10 \mu \mathrm{M}$ Tat. Trace $\mathrm{c}$ : liver mitochondria pretreated 1 min with $10 \mu \mathrm{M}$ DIDS, then 3 min with $10 \mu \mathrm{M}$ Tat. Trace d: liver mitochondria pretreated with $10 \mu \mathrm{M}$ DIDS only. Trace e: heart mitochondria (no pretreatment). Trace f: heart mitochondria pretreated for $3 \mathrm{~min}$ with $10 \mu \mathrm{M}$ Tat. Trace g: brain mitochondria (no pretreatment).Trace $\mathrm{h}$ : brain mitochondria pretreated for $3 \mathrm{~min}$ with $10 \mu \mathrm{M}$ Tat. Numbers along the traces are $\mathrm{nmol} \mathrm{O}_{2}$ consumed per min per mg protein. (b) Influence of Tat concentration on oxidative activities of liver, heart, and brain mitochondria. Oxygen consumption by purified mitochondria was measured after addition of succinate (as in (a)). Mitochondria were treated 3 min with the indicated concentrations of Tat. Then, oxygen uptake by purified mitochondria was measured after addition of succinate (as in (a)) in the absence (gray bars) or presence of (black bars) of exogenous cytochrome $c$. Histograms represents $\%$ mean respiratory activity $(n=3$; variability was $<5 \%)$. Calculations are as described under Materials and Methods

Tat on complex III activity, but agree on, and widen (to liver, brain, and heart), in mice and humans, the existence of a direct COX inhibition by HIV-1 Tat. The use of different lengths (1-72 versus $1-86$ ) or sources of Tat might have contributed to discrepancies at the level of complex III. As we have found that iron-sulfur (Fe-S) centers containing enzymes of the respirasome are not affected by Tat, it is highly improbable that Tat could directly induce ROS production from isolated mitochondria. However, we cannot exclude that ROS production could occur as a consequence of mitochondrial dysfunction and electron leak from the respiratory chain. ${ }^{35}$

Huo et al..$^{20}$ recently described an interesting mechanism in Jurkat $T$ cell lines, where Tat is acetylated at Lysine 28 , and thereby induces Bim translocation from microtubules to
Table 1 Tat effects on respiratory chain complex activities

$\begin{array}{cccc}\begin{array}{c}\text { Malonate- } \\ \text { sensitive }\end{array} & \begin{array}{c}\text { Antimycin- } \\ \text { sensitive }\end{array} & \begin{array}{c}\text { Rotenone- } \\ \text { sensitive }\end{array} & \begin{array}{c}\text { COX } \\ \text { (CIV) }\end{array} \\ \text { SCCR (CII-III) } & \text { QCCR (CIII) } & \text { NCCR (Cl+III) } & \end{array}$

Brain

homogenate

(nmol/min per mg protein)

\begin{tabular}{llllr}
\hline Co. & 16 & 48 & 20 & 63 \\
Tat $1 \mu \mathrm{M}$ & 15 & 45 & 20 & 2 \\
Buffer $(5 \mu)^{\text {a }}$ & - & - & - & 63 \\
\hline
\end{tabular}

Buffer $(5 \mu \mathrm{l})^{\mathrm{a}}$

45

Abbreviations: SCCR, succinate cytochrome $c$ reductase; QCCR, quinol cytochrome $c$ reductase; NCCR, NADH cytochrome $c$ reductase.

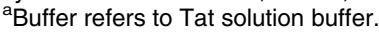

Values are means of triplicate experiments. Variability was $<5 \%$.

Activities of the various segments of the respiratory chain (succinate cytochrome $c$ and NADH cytochrome $c$ reductases) and of isolated complexes (decylubiquinol cytochrome $c$ reductase and cytochrome $c$ oxidase) were spectrophotometrically measured as described under Materials and Methods.

mitochondria, and favors apoptosis. ${ }^{19}$ Although it is plausible that such mechanism could occur in other tissues, we show clearly that the direct effect of Tat on isolated mitochondria does not require such modification as the Tat effects we have observed are reproduced with Tat[30-86].

A number of COX inhibitors have been previously described, including the well-known sodium azide, cyanide, carbon monoxide, nitric oxide, ${ }^{36-38}$ D-2-hydroxyglutaric acid, ${ }^{39}$ 4-hydroxy-2-nonenal, ${ }^{40}$ cephalosporins, ${ }^{41}$ or Alzheimer's amyloid precursor protein $695 .{ }^{42}$ However, HIV Tat is the first viral protein inhibiting COX. The respirometry experiments show that Tat effect with concentrations up to $5 \mu \mathrm{M}$ can be essentially counterbalanced by exogenous cytochrome $c$ addition. This indicates that the decrease of oxygen uptake observed under our experimental conditions is initially because of OMP and loss of cytochrome $c$ rather than COX inhibition. Taken together, these experiments suggest that when Tat reaches mitochondria (at the doses studied), it permeabilizes outer membrane to cytochrome $c$ but does not initially target COX. Under our in vitro conditions, inhibition of this latter complex by Tat only happens after disruption of mitochondrial membranes. Accordingly, in situ studies of immunochemistry-based detection of COX activity in Tattreated lymphocytes and neurons indicate that, when added at sublethal concentrations, Tat does not affect COX activity in intact cells. In the context of HIV infection, long-term chronic exposures to Tat might lead to a progressive and local mitochondrial accumulation and result in COX inhibition in the absence of, or before, OMP.

HIV infection is associated with profound cellular alterations including immune dysfunctions and neurological and cardiac complications. ${ }^{43-45}$ HIV Tat has been involved in many aspects of AIDS pathogenesis ${ }^{43-45}$ including apoptosis of different cell types. ${ }^{12,46-48}$ Hence, Tat cytotoxicity may be (at least in part) related to direct MMP induction, possibly triggering a cytochrome $c$-dependent apoptotic pathway. Other HIV-1 proteins, Vpr, Env, and PR, may also (directly or indirectly) affect mitochondrial function; Vpr via a direct PTP interaction, ${ }^{29} \mathrm{PR}$ by cleaving procaspase-8 and/or $\mathrm{Bcl}-2,{ }^{49,50}$ and Env by a cell-to-cell-mediated signaling pathway leading to Bax activation. ${ }^{51-54}$ This hints at the possibility that several apoptogenic HIV-1 proteins - Vpr, Tat, Env, and PR - cooperate at the mitochondrial level, contributing to 
a
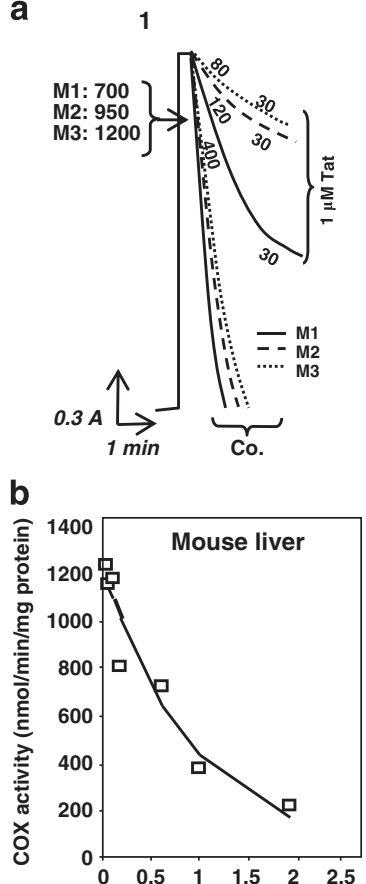

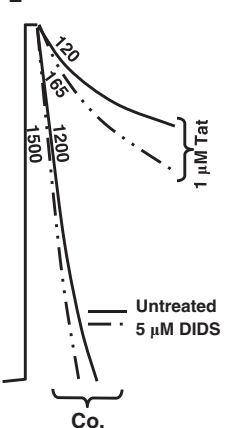

3

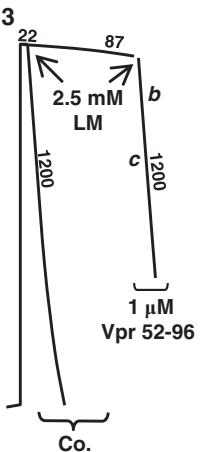

4

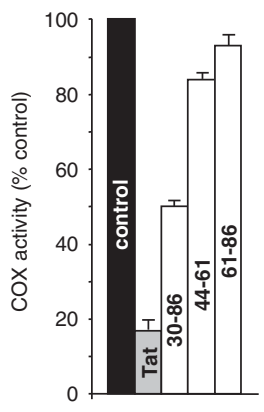

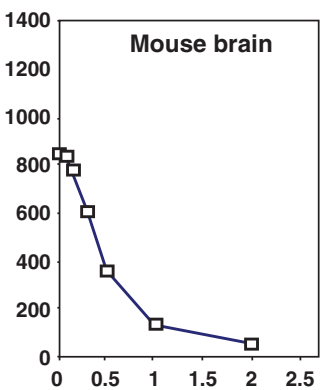

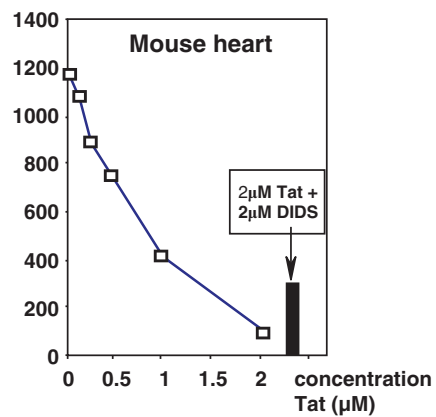

C

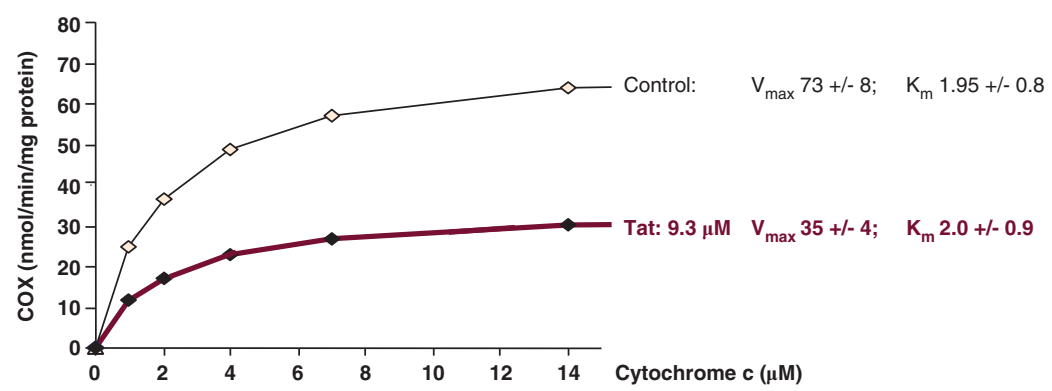

Figure 6 Cytochrome $c$ oxidase inhibition by Tat protein and Tat-derived peptides in permeabilized mitochondria. (a) Assay of cytochrome $c$ oxidase (COX) activity in detergent-treated ( $2.5 \mathrm{mM}$ dodecylmaltoside) mouse liver mitochondria. Part 1: Inhibition of cytochrome $c$ oxidation in permeabilized mitochondria induced by the addition of $1 \mu \mathrm{M}$ Tat, versus untreated mitochondria (Co.). Experiments were performed in three distinct media, namely COX (M1), swelling (M2), and electrode (M3) media. Part 2: Absence of protective effect of $5 \mu \mathrm{M}$ DIDS against COX inhibition by $1 \mu \mathrm{M}$ Tat[1-86]. Part 3: Similar experiment with $1 \mu \mathrm{M}$ of the negative control Vpr 52-96. Part 4: Effects of $1 \mu \mathrm{M}$ Tat[1-86] and Tat-derived peptides (30-86, 44-61 and 61-86) on COX activity $(n=3)$. (b) Inhibition of COX activity in mouse liver, brain, and heart mitochondria by increasing concentration of Tat[1-86]. DIDS was added at the indicated concentration. (c) $\mathrm{Km}$ (red Cyt c) calculation in the presence or not of full-length Tat

HIV-related cell damage in lymphocytes, ${ }^{55}$ neurons, and cardiomyocytes.

\section{Materials and Methods}

Animals. Mice were housed with a 12-h light/dark cycle. Free access to a standard laboratory chow diet and drinking water was provided. Experimental procedures were conducted according to the European Community guidelines for the care and use of experimental animals. Mice experimentation conducted at Theraptosis were approved by the local animal ethical committee (Biocitech, Romainville, France). Mice experimentation that was done at Inserm U676 was approved by the animal ethical institutional review committee, according to the INSERM guidelines, and was carried out in accordance with the European Community guidelines for the care and use of experimental animals.

Mitochondria isolation and purification. Liver and heart mitochondria were isolated from 4- to 6-week-old BALB/c mice (IFFA CREDO, Saint-Germain sur I'Arbresle, France). Liver mitochondria were prepared by standard differential centrifugations followed by Percoll purification as described previously. ${ }^{32}$ Mice hearts were minced and homogenized with a Dounce homogenizer in buffer containing
$300 \mathrm{mM}$ sucrose, $5 \mathrm{mM}$ TES (N-[tris(hydroxymethyl)methyl]-2-aminoethanesulfonic acid, 2-[(2-hydroxy-1,1-bis(hydroxymethyl)ethyl)amino]ethanesulfonic acid) pH 7.2, $0.2 \mathrm{mM}$ EGTA, and $1 \mathrm{mg} / \mathrm{ml} \mathrm{BSA}$. The suspension was centrifuged at $800 \mathrm{~g}$ for $10 \mathrm{~min}$ and the resulting supernatant at $10000 \mathrm{~g}$ for $10 \mathrm{~min}$ at $4^{\circ} \mathrm{C}$. The pellet was resuspended in homogenization buffer before to be layered on a three-phase percoll density gradient. After centrifugation (for $10 \mathrm{~min}$ at $8740 \mathrm{~g}$ ), mitochondria were collected from the lower interface and washed in homogenization buffer by centrifugation at $10000 \mathrm{~g}(10 \mathrm{~min})$. Brain mitochondria were isolated according to previously described protocols. ${ }^{56,57}$ Isolated mitochondria were subjected to various assays for integrity and functionality as described..$^{32}$ Alternatively, mitochondria were isolated from mouse heart, brain, and liver by differential centrifugation (according to Musatov et $a l^{40}$ ), and used in spectrophotometry, spectrofluorimetry, and respirometry assays. We did not find significant differences in most read-outs when using the alternative purification protocols as compared with the percoll density gradient-based purifications. Only flow cytometry-based assays strictly requested gradient-based purification.

Human tissue. Human liver, brain, and heart homogenates were prepared from 5 to $10 \mathrm{mg}$ post-mortem tissues for diagnostic purpose with informed consents. Microaliquots (10-30 $\mu$ left after diagnostic investigation) used in this study presented normal activity of the respiratory chain complexes. ${ }^{34}$ 
Synthesis of full-length Tat and Tat peptides. Tat[1-86] protein from HIV-1 Lai strain was prepared using the NCL method introduced by Dawson et al., ${ }^{23}$ as described in Supplementary Materials and Methods. Other Tat fragments used in this study, namely Tat [30-86], Tat [48-86], Tat [61-86], Tat [30-61], and Tat [44-61], were assembled using solid-phase Fmoc chemistry, purified, and analyzed as described for the Tat [22-86] fragment. ${ }^{58}$

Reagents. ADP, BA, ruthenium red, DIDS, and carbonyl cyanide $m$ chlorophenylhydrazone ( $\mathrm{mCICCP}$ ) were purchased from SIGMA (Saint Quentin Fallavier, France), CsA from BIOMOL Research Laboratories (Le Perray-en-Yvelines, France), and the recombinant proteins $\mathrm{Bcl}-2$ and $\mathrm{Bcl}-\mathrm{xL}$ from Oncogene Research products (Oncogene Research Products, Merck, VWR International, Fontenay-sousBois, France). BCB ((6)-1-(3,6-dibromocarbazol-9-yl)-3-piperazin-1-yl-propan-2-ol) was purchased from Calbiochem (San Diego, CA, USA) and BIP-V5 (H-Val-ProMet-Leu-Lys-OH; cat. no. 196810) was purchased from Calbiochem (Nottingham, UK).

Detection of large amplitude swelling and $\Delta \Psi_{m}$ loss. Mitochondria were resuspended in a buffer, referred as the swelling buffer, containing $0.2 \mathrm{M}$ sucrose, $5 \mathrm{mM}$ succinate, $10 \mathrm{mM}$ MOPS (3-[ $N$-morpholino]-propanesulfonic acid), $1 \mathrm{mM} \mathrm{KH}_{2} \mathrm{PO}_{4}, 2 \mu \mathrm{M}$ Rotenone, and $10 \mu \mathrm{M}$ EGTA at $\mathrm{pH}$ 7.4. Large amplitude swelling was determined by measuring absorbance at $545 \mathrm{~nm}\left(A_{545}\right)$. Percentages of specific swelling were calculated as follows: $\left(A_{\text {init }}-A_{\text {Reagent }}\right) \times 100 /\left(A_{\text {init }}-A_{\text {Ca2 }+}\right)$, where $A_{\mathrm{Ca} 2+}, A_{\text {Reagent }}$, and $A_{\text {init }}$ correspond to the absorbance value obtained for $\mathrm{CaCl}_{2}$-treated, reagent-treated, and pretreated mitochondria respectively. $\Delta \Psi_{\mathrm{m}}$ loss was assessed by $5,5^{\prime}, 6,6^{\prime}$,-tetracholoro-1,1,3,3'-tetraethylbenzimidazolylcarbocya nine iodide (JC-1; Molecular Probes, Saint Aubin, France) incorporation followed by fixed- and real-time flow cytometry analysis. ${ }^{32}$ Alternatively, mitochondrial swelling and $\Delta \Psi_{\mathrm{m}}$ were analyzed by spectrophotometry and spectrofluorimetry in 96-well plates $(22 \mu \mathrm{g} / \mathrm{ml})$ as described. ${ }^{59}$ Briefly, isolated mitochondria were incubated in swelling buffer supplemented with $1 \mu \mathrm{M}$ rhodamine 123 (Rh123; Molecular Probes). Then, absorbance at $545 \mathrm{~nm}$ and Rh123 fluorescence (excitation $485 \mathrm{~nm}$, emission $535 \mathrm{~nm}$ ) were recorded during 30 cycles of 1 min using a fluorescence multi-well plate reader (Infinite 200, Tecan, Männedorf, Switzerland).

Cytochrome $c$ release detection. Mitochondria ( $30 \mu \mathrm{g}$ protein) isolated from liver, brain, and heart were incubated in swelling buffer with $20 \mu \mathrm{g} / \mathrm{ml}$ Alamethicin (Ala, positive control, $100 \%$ baseline for ELISA), or Tat peptides for $30 \mathrm{~min}$ at $30^{\circ} \mathrm{C}$. After a 7 -min centrifugation at $10000 \mathrm{~g}\left(4^{\circ} \mathrm{C}\right)$, proteins contained in supernatant were analyzed for quantification of cytochrome $c$ release using ELISA kit from MBL (Cliniscience, Montrouge, France), or subjected to immunoblot detection of cytochrome $c$ (mouse mAb clone 7H8.2C12; PharMingen, BD Biosciences, Le Pont de Claix, France).

Polarographic studies. Polarographic studies were performed using a Clark oxygen electrode (Hansatech Ltd, Norfolk, UK) in a magnetically stirred 250- $\mu$ l cell thermostated at $37^{\circ} \mathrm{C}$ as previously described. ${ }^{34}$ Experiments were carried out in an electrode medium consisting of $0.3 \mathrm{M}$ mannitol, $5 \mathrm{mM} \mathrm{MgCl}_{2}, 10 \mathrm{mM} \mathrm{KCl}, 10 \mathrm{mM}$ phosphate buffer $\mathrm{pH} 7.4$, and $1 \mathrm{mg} / \mathrm{ml} \mathrm{BSA}$. The relative respiratory activity of mitochondria treated by Tat was calculated as follows: respiratory activity= $\left(\mathrm{O}_{2}\right.$ Tat $-\mathrm{O}_{2}$ co. $) \times 100 / 0_{2}$ co. where $\mathrm{O}_{2}$ Tat and $\mathrm{O}_{2}$ co. correspond to oxygen consumption of Tat-treated and control mitochondria, respectively.

Spectrophotometric assays. Respiratory chain enzyme activities were spectrophotometrically measured at $37^{\circ} \mathrm{C}$ in $1 \mathrm{ml}$ of $10 \mathrm{mM}$ phosphate buffer $\mathrm{pH} 6.5$, added with $1 \mathrm{mg} / \mathrm{ml} \mathrm{BSA}$ using a double wavelength spectrophotometer $(550-540 \mathrm{~nm})$ (Cary 50, Varian, Melbourne, Australia) ${ }^{34} \mathrm{COX}$ (CIV) activity was assayed in the presence of $10 \mu \mathrm{M}$ reduced cytochrome $c$ and $2.5 \mathrm{mM}$ lauryl maltoside. Malonate-sensitive succinate cytochrome $c$ reductase (complex II + III), rotenone sensitive cytochrome $c$ reductase (complex I+ III) and antimycin-sensitive decylubiquinol-cytochrome $c$ reductase (complex III) were measured under standard conditions as previously described. ${ }^{34}$

Electron microscopy. Isolated mitochondria were fixed with $2 \%$ glutaraldehyde in $0.1 \mathrm{M}$ cacodylate buffer, $\mathrm{pH} 7.2$, for $3 \mathrm{~h}$ at $4^{\circ} \mathrm{C}$. After several washes with this buffer, specimens were post-fixed with $1 \%$ osmium tetroxide containing $1.5 \%$ potassium cyanoferrate, dehydrated in gradual ethanol (30-100\%), and embedded in Epon. Thin sections $(70 \mathrm{~nm})$ were collected onto 200 mesh cupper grids, and counterstained with uranyl acetate and lead citrate before examination with a Philips CM12 transmission electron microscope (Philips Research, Eindhoven, The Netherlands) at $80 \mathrm{kV}$.

Statistical analysis. Data obtained on isolated mitochondria were analyzed using Student's $t$-test for all pairwise comparisons of mean responses among the different treatments or conditions tested. Results are presented as the mean \pm S.D. for replicate experiments. Differences were considered significant when $P<0.05\left(^{*}\right)$.

\section{Conflict of Interest}

The authors declare no conflict of interest.

Acknowledgements. This work was supported by the French Ministry of Research (Bio-Ingeniery Program) to EJ (No. 01H0476), CB (No. 01H0480), and SM (No. 01H0478), by Agence Nationale pour la Valorisation de la Recherche (ANVAR) to EJ (No. R0209333Q), by Sidaction to SM, by Association Française contre les Myopathies (AFM) and Ammi (Association contre les Maladies Mitochondriales) to PR, by Centre National pour la Recherche Scientifique (CNRS) to SM and PR, and Institut National de la Santé et de la Recherche Médicale (Inserm) to PR and EJ. In addition, OC was supported by Sidaction, DR by ANVAR (No. K0109377Q), and AL by Centre Régional d'Innovation et de Transfert de Technologie (CRITT) d'lle de France.

\section{Author Contributions}

EJ and PR, designed research; HL, J-JB, AB-S, OC, RE-K, J-PB, MB, PR, EJ, AL, MP, NB, CP, and AD performed research; $O C$ and J-PB contributed Tat and Tat peptides; DR, CB, J-PB, SM, PR, and EJ analyzed data; EJ wrote the paper.

1. Elston T, Wang H, Oster G. Energy transduction in ATP synthase. Nature 1998; 391 510-513.

2. Noji H, Yoshida M. The rotary machine in the cell, ATP synthase. J Biol Chem 2001; 276 1665-1668.

3. Briere JJ, Chretien D, Benit P, Rustin P. Respiratory chain defects: what do we know for sure about their consequences in vivo? Biochim Biophys Acta 2004; 1659: 172-177.

4. Kroemer G, Galluzzi L, Brenner C. Mitochondrial membrane permeabilization in cell death. Physiol Rev 2007; 87: 99-163.

5. Tait S, Green DR. Mitochondria and cell death: outer membrane permeabilization and beyond. Nat Rev Mol Cell Biol 2010; 11: 621-632.

6. Sugioka R, Shimizu S, Tsujimoto Y. Fzo1, a protein involved in mitochondrial fusion, inhibits apoptosis. J Biol Chem 2004; 279: 52726-52734.

7. Nakagawa T, Shimizu S, Watanabe T, Yamaguchi 0 , Otsu $\mathrm{K}$, Yamagata $\mathrm{H}$ et al. Cyclophilin D-dependent mitochondrial permeability transition regulates some necrotic but not apoptotic cell death. Nature 2005; 434: 652-658.

8. Jourdain A, Martinou JC. Mitochondrial outer-membrane permeabilization and remodelling in apoptosis. Int J Biochem Cell Biol 2009; 41: 1884-1889.

9. Boya P, Pauleau AL, Poncet D, Gonzalez-Polo RA, Zamzami N, Kroemer G. Viral proteins targeting mitochondria: controlling cell death. Biochim Biophys Acta 2004; 1659: 178-189.

10. Galluzzi L, Brenner C, Morselli E, Touat Z, Kroemer G. Viral control of mitochondria apoptosis. PLoS Pathog 2008; 4: e1000018.

11. Giacca M. The HIV-1 Tat protein: a multifaceted target for novel therapeutic opportunities. Curr Drug Targets Immune Endocr Metabol Disord 2004; 4: 277-285.

12. Romani B, Engelbrecht $S$, Glashoff RH. Functions of Tat: the versatile protein of human immunodeficiency virus type 1. J Gen Virol 2010; 91: 1-12.

13. Noonan D, Albini A. From the outside in: extracellular activities of HIV Tat. Adv Pharmacol 2000; 48: 229-250.

14. Rumbaugh JA, Steiner J, Sacktor N, Nath A. Developing neuroprotective strategies for treatment of HIV-associated neurocognitive dysfunction. Futur HIV Ther 2008; 2: 271-280.

15. Li W, Li G, Steiner J, Nath A. Role of Tat protein in HIV neuropathogenesis. Neurotox Res 2009; 16: 205-220.

16. Cantaluppi V, Biancone L, Boccellino M, Doublier S, Benelli R, Carlone S et al. HIV type 1 Tat protein is a survival factor for Kaposi's sarcoma and endothelial cells. AIDS Res Hum Retroviruses 2001; 17: 965-976.

17. Flores SC, Marecki JC, Harper KP, Bose SK, Nelson SK, McCord JM. Tat protein of human immunodeficiency virus type 1 represses expression of manganese superoxide dismutase in HeLa cells. Proc Natl Acad Sci USA 1993; 90: 7632-7636.

18. Macho A, Calzado MA, Jiménez-Reina L, Ceballos E, León J, Muñoz E. Susceptibility of HIV-1-TAT transfected cells to undergo apoptosis. Biochemical mechanisms. Oncogene 1999; 18: 7543-7551.

19. Chen D, Wang M, Zhou S, Zhou Q. HIV-1 Tat targets microtubules to induce apoptosis, a process promoted by the pro-apoptotic Bcl-2 relative Bim. EMBO J 2002; 21: 6801-6810. 
20. Huo L, Li D, Sun L, Liu M, Shi X, Sun $X$ et al. Tat acetylation regulates its actions on microtubule dynamics and apoptosis in T lymphocytes. J Pathol 2011; 223: 28-36.

21. Norman JP, Perry SW, Kasischke KA, Volsky DJ, Gelbard HA. HIV-1 trans activator of transcription protein elicits mitochondrial hyperpolarization and respiratory deficit, with dysregulation of complex IV and nicotinamide adenine dinucleotide homeostasis in cortical neurons. J Immunol 2007; 178: 869-876.

22. Raidel SM, Haase C, Jansen NR, Russ RB, Sutliff RL, Velsor LW et al. Targeted myocardial transgenic expression of HIV Tat causes cardiomyopathy and mitochondrial damage. Am J Physiol Heart Circ Physiol 2002; 282: H1672-1678.

23. Dawson PE, Muir TW, Clark-Lewis I, Kent SB. Synthesis of proteins by native chemical ligation. Science 1994; 266: 776-779.

24. Peloponese Jr JM, Collette Y, Grégoire C, Bailly C, Campèse D, Meurs EF et al. Full peptide synthesis, purification, and characterization of six Tat variants. Differences observed between HIV-1 isolates from Africa and other continents. J Biol Chem 1999; 274 11473-11478.

25. Partidos CD, Moreau E, Chaloin O, Tunis M, Briand JP, Desgranges $C$ et al. A synthetic HIV-1 Tat protein breaches the skin barrier and elicits Tat-neutralizing antibodies and cellular immunity. Eur J Immunol 2004; 34: 3723-3731.

26. Partidos CD, Hoebeke J, Moreau E, Chaloin O, Tunis M, Belliard G et al. The binding affinity of double-stranded RNA motifs to HIV-1 Tat protein affects transactivation and the neutralizing capacity of anti-Tat antibodies elicited after intranasal immunization. Eur $J$ Immunol 2005; 35: 1521-1529.

27. Chaloin O, Peter JC, Briand JP, Masquida B, Desgranges C, Muller S et al. The N-terminus of HIV-1 Tat protein is essential for Tat-TAR RNA interaction. Cell Mol Life Sci 2005; 62 355-361.

28. Marzo I, Brenner C, Zamzami N, Susin SA, Beutner G, Brdiczka D et al. The permeability transition pore complex: a target for apoptosis regulation by caspases and bcl-2-related proteins. J Exp Med 1998; 187: 1261-1271.

29. Jacotot E, Ravagnan L, Loeffler M, Ferri KF, Vieira HL, Zamzami N et al. The HIV-1 vira protein $\mathrm{R}$ induces apoptosis via a direct effect on the mitochondrial permeability transition pore. J Exp Med 2000; 191: 33-46.

30. Jacotot E, Ferri KF, El Hamel C, Brenner C, Druillennec S, Hoebeke J et al. Control of mitochondrial membrane permeabilization by adenine nucleotide translocator interacting with HIV-1 viral protein R and Bcl-2. J Exp Med 2001; 193: 509-519.

31. Norman JP, Perry SW, Reynolds HM, Kiebala M, De Mesy Bentley KL, Trejo M et al. HIV-1 Tat activates neuronal ryanodine receptors with rapid induction of the unfolded protein response and mitochondrial hyperpolarization. PLoS One 2008; 3: e3731.

32. Lecoeur H, Langonné A, Baux L, Rebouillat D, Rustin $P$, Prévost MC et al. Real-time flow cytometry analysis of permeability transition in isolated mitochondria. Exp Cell Res 2004; 294: 106-117.

33. Buron N, Porceddu M, Brabant M, Desgué D, Racoeur C, Lassalle M et al. Use of human cancer cell lines mitochondria to explore the mechanisms of $\mathrm{BH} 3$ peptides and ABT-737induced mitochondrial membrane permeabilization. PLoS One 2010; 5: e9924.

34. Rustin P, Chretien D, Bourgeron T, Gérard B, Rötig A, Saudubray JM et al. Biochemical and molecular investigations in respiratory chain deficiencies. Clin Chim Acta 1994; 228 . $35-51$

35. Buccigrossi V, Laudiero G, Nicastro E, Miele E, Esposito F, Guarino A. The HIV-1 transactivator factor (Tat) induces enterocyte apoptosis through a redox-mediated mechanism. PLoS One 2011; 6: e29436.

36. Cleeter MW, Cooper JM, Darley-Usmar VM, Moncada S, Schapira AH. Reversible inhibition of cytochrome c oxidase, the terminal enzyme of the mitochondrial respiratory chain, by nitric oxide. Implications for neurodegenerative diseases. FEBS Lett 1994; 345: 50-54.

37. Cooper CE. Nitric oxide and cytochrome oxidase: substrate, inhibitor or effector? Trends Biochem Sci 2002; 27: 33-39.

38. Yuyama K, Yamamoto H, Nishizaki I, Kato T, Sora I, Yamamoto T. Caspase-independent cell death by low concentrations of nitric oxide in $\mathrm{PC} 12$ cells: involvement of cytochrome $\mathrm{C}$ oxidase inhibition and the production of reactive oxygen species in mitochondria $J$ Neurosci Res 2003; 73: 351-363.

39. da Silva C, Ribeiro CA, Leipnitz G, Dutra-Filho CS, Wyse AT, Wannmacher CM et al. Inhibition of cytochrome c oxidase activity in rat cerebral cortex and human skeletal muscle by D-2-hydroxyglutaric acid in vitro. Biochim Biophys Acta 2002; 1586: 81-91.

40. Musatov A, Carroll CA, Liu YC, Henderson GI, Weintraub ST, Robinson NC. Identification of bovine heart cytochrome $c$ oxidase subunits modified by the lipid peroxidation product 4-hydroxy-2-nonenal. Biochemistry 2002; 41: 8212-8220.

41. Kiyomiya K, Matsushita N, Kurebe M, Nakagawa H, Matsuo S. Mitochondrial cytochrome $\mathrm{c}$ oxidase as a target site for cephalosporin antibiotics in renal epithelial cells (LLC-PK(1)) and renal cortex. Life Sci 2002; 72: 49-57.

42. Anandatheerthavarada HK, Biswas G, Robin MA, Avadhani NG. Mitochondrial targeting and a novel transmembrane arrest of Alzheimer's amyloid precursor protein impairs mitochondrial function in neuronal cells. J Cell Biol 2003; 161: 41-54.

43. van de Bovenkamp M, Nottet HS, Pereira CF. Interactions of human immunodeficiency virus-1 proteins with neurons: possible role in the development of human immunodeficiency virus-1-associated dementia. Eur J Clin Invest 2002; 32: 619-627.

44. Albright AV, Soldan SS, Gonzalez-Scarano F. Pathogenesis of human immunodeficiency virus-induced neurological disease. J Neurovirol 2003; 9: 222-227.

45. Barbaro G. HIV infection, highly active antiretroviral therapy and the cardiovascular system. Cardiovasc Res 2003; 60: 87-95

46. Haughey NJ, Mattson MP. Calcium dysregulation and neuronal apoptosis by the HIV-1 proteins Tat and gp120. J Acquir Immune Defic Syndr 2002; 31 (Suppl 2): S55-S61.

47. Alimonti JB, Ball TB, Fowke KR. Mechanisms of CD4+ T lymphocyte cell death in human immunodeficiency virus infection and AIDS. J Gen Virol 2003; 84: 1649-1661.

48. Desgranges C, Muller S. HIV-1 Tat and apoptotis death. In: Badley A et al. (eds). Cell Death During HIV Infection, Chap. 9. CRC Press: Boca Raton, FL, 2006, pp 143-148.

49. Strack PR, Frey MW, Rizzo CJ, Cordova B, George HJ, Meade R et al. Apoptosis mediated by HIV protease is preceded by cleavage of Bcl-2. Proc Natl Acad Sci USA 1996; 93: 9571-9576.

50. Nie Z, Bren GD, Rizza SA, Badley AD. HIV Protease Cleavage of Procaspase 8 is Necessary for Death of HIV-Infected Cells. Open Virol J 2008; 2: 1-7.

51. Ferri KF, Jacotot E, Blanco J, Esté JA, Zamzami N, Susin SA et al. Apoptosis control in syncytia induced by the HIV type 1-envelope glycoprotein complex: role of mitochondria and caspases. J Exp Med 2000; 192: 1081-1092.

52. Castedo M, Ferri KF, Blanco J, Roumier T, Larochette N, Barretina $\mathrm{J}$ et al. Human immunodeficiency virus 1 envelope glycoprotein complex-induced apoptosis involves mammalian target of rapamycin/FKBP12-rapamycin-associated protein-mediated p53 phosphorylation. J Exp Med 2001; 194: 1097-1110.

53. Castedo M, Roumier T, Blanco J, Ferri KF, Barretina J, Tintignac LA et al. Sequential involvement of Cdk1, mTOR and p53 in apoptosis induced by the HIV-1 envelope. EMBO J 2002; 21: 4070-4080

54. Perfettini J, Nardacci R, Séror C, Bourouba M, Subra F, Gros L et al. The tumor suppressor protein PML controls apoptosis induced by the HIV-1 envelope. Cell Death Differ 2009; 16 : 298-311.

55. Cummins NW, Badley AD. Mechanisms of HIV-associated lymphocyte apoptosis: 2010. Cell Death Dis 2010; 1: e99.

56. Sims NR, Anderson MF. Isolation of mitochondria from rat brain using Percoll density gradient centrifugation. Nat Protoc 2008; 3: 1228-1239.

57. Wang X, Leverin AL, Han W, Zhu C, Johansson BR, Jacotot E et al. Isolation of brain mitochondria from neonatal mice. J Neurochem 2011; 119: 1253-1261.

58. Neimark J, Briand JP. Development of a fully automated multichannel peptide synthesizer with integrated TFA cleavage capability. Pept Res 1993; 6: 219-228.

59. Brabant M, Baux L, Casimir R, Briand JP, Chaloin O, Porceddu M et al. A flavivirus protein M-derived peptide directly permeabilizes mitochondrial membranes, triggers cell death and reduces human tumor growth in nude mice. Apoptosis 2009; 14: $1190-1203$

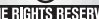

Cell Death and Disease is an open-access journal published by Nature Publishing Group. This work is licensed under the Creative Commons Attribution-Noncommercial-No Derivative Works 3.0 Unported License. To view a copy of this license, visit http://creativecommons.org/licenses/by-nc-nd/3.0/

Supplementary Information accompanies the paper on Cell Death and Disease website (http://www.nature.com/cddis) 